\title{
3 Research Square

\section{Mineral composition of wheat species as influenced by different fertilizer sources and different weed control practices}

Sancar Bulut ( $\sim$ sancarbulut@kayseri.edu.tr)

Kayseri University https://orcid.org/0000-0002-6261-0256

Ali Öztürk

Ataturk University https://orcid.org/0000-0001-7673-114X

Nesrin Yıldız

Ataturk University https://orcid.org/0000-0002-8179-6228

Mehmet Murat Karaoğlu

Ataturk University https://orcid.org/0000-0002-9919-8824

\section{Research Article}

Keywords: Organic wheat, genotypes, seeding rate, fertilization, mineral content

Posted Date: March 18th, 2022

DOI: https://doi.org/10.21203/rs.3.rs-1107511/v2

License: (a) (i) This work is licensed under a Creative Commons Attribution 4.0 International License.

Read Full License

Version of Record: A version of this preprint was published at Gesunde Pflanzen on May 2nd, 2022. See the published version at https://doi.org/10.1007/s10343-022-00671-w. 


\section{Abstract}

This research was carried out to determine the effects of agronomic practices on the mineral composition of organically-grown wheat species. In terms of all nutrients evaluated, the mineral content of wheat showed significant differences according to crop years, varieties, weed control methods and fertilizer sources. As the average of all factors, the $\mathrm{Cu}, \mathrm{Fe}, \mathrm{Mn}, \mathrm{Se}, \mathrm{Zn}, \mathrm{Cd}, \mathrm{Co}, \mathrm{Cr}, \mathrm{Ni}$ and $\mathrm{Pb}$ contents of the ground wheat grain were; $3.93,42.8,79.6,0.549,11.34,0.012,0.140,0.194,3.71$ and $0.269 \mathrm{mg} / \mathrm{kg}$, respectively. According to the wheat varieties, the Kırik was superior in terms of $\mathrm{Cu}, \mathrm{Fe}, \mathrm{Se}, \mathrm{Zn}, \mathrm{Co}$ and $\mathrm{Cr}$, and the Dogu88 was superior in terms of $\mathrm{Mn}, \mathrm{Cd}$, and $\mathrm{Ni}$. The effect of weed control methods on mineral content was variable. According to fertilizer sources, the highest mineral content was obtained from the control plots without fertilizer treatments. The lowest mineral contents were obtained from chemical fertilization, cattle manure and organic fertilizer applications. There was no significant increase in the mineral content of wheat with organic fertilization, however, organic agriculture still preserves its place in terms of healthy food. As a result, it has been determined that the values obtained for all mineral elements were not at a level that pose a risk on the environment, human and animal health according to WHO.

\section{Introduction}

High nutrition quality of wheat grain is an important precondition for human and animal health. It appears that about half of all diseases are caused by nutritional disorders. However, the consequences of many disorders remain hidden because of the complexity of the relationship between food quality and health and because of the time lag between cause and effect. Agriculture that produces healthy food contributes to the prevention of diseases and this aspect is often underestimated. The effects of food quality on health can be assessed by determining the value of the ingredients in food products or by medical indices of health status where nutritional disorders are not directly observed. The problem of the latter is that of latent (slight or hidden) deficiencies, which occur much more frequently than do acute (visible) deficiencies.

Wheat is the most important staple crop in temperate zones and is in increasing demand in countries undergoing urbanization and industrialization. In addition to being a major source of starch and energy, wheat also provides substantial amounts of a number of components which are essential or beneficial for health, notably protein, vitamins (notably B vitamins), dietary fiber, and minerals (Shewry and Hey, 2015). Wheat grain also contains a number of elements ( $\mathrm{Cu}, \mathrm{Zn}, \mathrm{Fe}, \mathrm{Ni}, \mathrm{Mn})$ vital to our biological functions, but hazardous to our health in high concentrations (Conti et al. 2000; Skrbic and Onjia 2007). It also contains some toxic elements ( $\mathrm{As}, \mathrm{Pb}, \mathrm{Hg}, \mathrm{Cd}$ ). There are three groups of minerals of interest to the food industry, science and nutrition specialists (Stefanovic et al. 2008): (a) essential to human ( $\mathrm{Cu}, \mathrm{Ca}$, $\mathrm{Fe}, \mathrm{K}$ and $\mathrm{Mg}$ ) (b) essential to plants and one or more animal species however not for humans ( $\mathrm{As}, \mathrm{Cd}, \mathrm{Ni}$, and others) and (c) toxic or used in therapeutic dosages (Al, Ba, Hg). Still, it would be important to emphasize that they are all toxic and what makes them non-toxic are the amounts (dosages) themselves. The fine line between the essential and toxic is relative to the amount and intake through food. In agronomic studies related to wheat, the parts related to mineral content are generally not taken into 
account. Heavy metals are important and highly persistent environmental pollutants, and their toxicity is an increasingly important problem for ecological and nutritional phenomena (Ahmad et al. 2019; Munir et al. 2019; Siddique et al. 2019; Wajid et al. 2020; Ugulu et et al. 2021). Literature searches have shown that there are not enough studies on the effects of fertilizer sources and other agronomic practices (like showing densities or weed control treatment on mineral content of wheat plants in agricultural systems. According to the Ugulu et al. (2021), the heavy metal/metalloid concentrations in the wheat grains ranged from 12.95 to $25.83,1.03$ to $1.11,16.83$ to $20.26,0.92$ to $0.98,0.504$ to $1.997,2.24$ to 5.98 , and 0.493 to $1.154 \mathrm{mg} / \mathrm{kg}$ for $\mathrm{Zn}, \mathrm{Co}, \mathrm{Fe}, \mathrm{Cd}, \mathrm{Pb}, \mathrm{Cu}$, and $\mathrm{Cr}$, respectively.

The mineral content of wheat is not evaluated much in agronomic studies. Whereas; the mineral content of wheat is different according to the agronomic applications, the climate-soil conditions of the region and the varieties. In fact, as a result of agronomic practices, the mineral content of the wheat grain may exceed the acceptable limits for the environment, human and animal health. For this reason, health problems can occur insidiously. In the present study the effects of different fertilizer sources and weed control methods on mineral contents of two wheat varieties were investigated for two years.

\section{Material And Methods}

Wheat seeds evaluated in the current study were obtained from a previous research carried out in Ataturk University, Agricultural Research and Extension Center, during the cropping seasons of 2006-07, 2007-08 and 2008-09. The experiment was carried out using a completely randomized design in $2 \times 3 \times 7$ factorial scheme, with 3 replicates. In previous study, the factors were 2 wheat varieties (Kırik and Doğu-88), 3 weed control management practices [weedy control ( 475 seeds $\left.\mathrm{m}^{-2}\right)$, hand weeding ( 475 seeds $\mathrm{m}^{-2}+\mathrm{HW}$ ), and dense sowing ( 625 seeds $\left.\mathrm{m}^{-2}\right)$ ], and seven fertilizer sources [Control, standard inorganic (NP), Bio Organic (Bio), Bio Organic SR (Bio SR), Leonardite, Organic Fertilizer (OF), Cattle Manure (CM)]. After harvesting, the spikes were threshed and grains were stored at $-20^{\circ} \mathrm{C}$. Dried seed samples were grinded and etched in microwave (Berghof Speedwave, Germany) using $2 \mathrm{ml}$ of $35 \% \mathrm{H}_{2} \mathrm{O}_{2}$ and $5 \mathrm{ml}$ of $65 \% \mathrm{HNO}_{3}$. Following the digestions, seed mineral contents Copper ( $\mathrm{Cu}$ ), Iron ( $\mathrm{Fe})$, Manganese (Mn), Selenium (Se) Zinc (Zn), Cadmium (Cd), Cobalt (Co), Chrome (Cr), Nickel (Ni) and Lead (Pb) were analyzed in an Inductively Coupled Plasma Mass Spectrometry (ICP-MS; Agilent 7500a) in laboratories of Technological Research and Extention Center of Erciyes University (TAUM). To check related elemental measurements, reference leaf samples from National Institute of Standards and Technology (Gaithersburg, MD, USA) were used in present study.

Properties of the experimental soils, climate characteristics, crop management, sowing and harvesting dates, application rates, and important characteristics of OMs were provided in our previous study (Öztürk et al. 2012).

Statistical Analysis: The significance of treatment means was evaluated with standard analysis of variance techniques. Mean values of each treatment were presented in tables. The DUNCAN test was 
used to compare the differences among treatment means at the 0.05 probability level. The statistical analyses were performed with SAS.

\section{Results And Discussion}

In the current study, the effect of different fertilizer sources (organic matter, organic fertilizer and mineral fertilizer) and weed control treatments (high seeding rates and hand weeding) on the mineral content (Cu, $\mathrm{Fe}, \mathrm{Mn}, \mathrm{Se}, \mathrm{Zn}, \mathrm{Cd}, \mathrm{Co}, \mathrm{Cr}, \mathrm{Ni}$ and $\mathrm{Pb}$ ) of wheat (Dogu-88 and Kirik genotypes) samples were investigated. The effects of production years, wheat varieties, weed control methods and fertilizer sources on mineral content were significant $(P<0.05)$, (Table 1 and 2$)$.

The differences between the production years have been significant in terms of all investigated mineral elements. For all elements, the highest values were obtained in the second crop year when the climatic conditions were favorable for wheat growth. The lowest values were obtained in the first production year when rainfall was less than the other years.

Copper (Cu): Average cupper content of entire treatments was found to be 3.93 ppm. Kırik and Doğu-88 varieties had 4.08 and 3.79 ppm Cu concentrations, respectively and copper concentrations of weedy control, hand weeding, and dense sowing were 3.75, 3.67 and 4.38 ppm, respectively. Copper concentrations of control, NP, Bio, Bio SR, Leonardite, OF and CM fertilizer sources were 6.74, 1.75, 5.47, 4.79, 2.80, 3.03 and 2.99 ppm, respectively. Copper is an essential trace element present in plants and animals (Dogan et al. 2010). The deficiency of Cu causes bone disorders, higher risks for infection, abnormalities in glucose metabolism (Chen et al. 2020; Grzeszczak, et al. 2020) and adverse effects on heart health (Klevay, 2000). Average of entire treatments Cu content was 3.93 ppm. The Cu content obtained in the study conducted by Stefanovic et al. (2008) is in agreement with our results. The results of the present study indicated that Cu content in wheat grains was below the acceptable limit 73.30 $\mathrm{mg} / \mathrm{kg}$ as suggested by the FAO/WHO (2001). Lakhdar et al. (2009) and Ugulu et al. (2021) reported lower $\mathrm{Cu}$ value in wheat grown under farmyard manure and wastewater applied conditions as compared with the present study. Lakhdar et al. (2009) reported lower Cu value $(2.58 \mathrm{mg} / \mathrm{kg})$ in wheat grown under farmyard manure applied condition. On the other hand, Ugulu et al. (2021) reported that high Cu value in wheat grown under wastewater applied condition was obtained in Pakistan.

Iron (Fe): It has been estimated that globally $43 \%$ of children and $29 \%$ of women of reproductive age have anemia, and about half of these cases result from iron deficiency (WHO, 2015). Average Fe content of entire treatments was 42.8 ppm. Kırik and Doğu-88 varieties had of 43.6 and 42.0 ppm Fe concentrations, respectively. Iron concentrations of weedy control, hand weeding, and dense sowing were 46.1, 44.5 and 37.8 ppm, respectively; and Fe concentrations of control, NP, Bio, Bio SR, Leonardit, OF and CM fertilizer sources were 60.2, 27.7, 45.1, 50.8, 41.9, 34.2 and 40.0 ppm respectively. The highest Fe content was obtained from control treatment (no fertilizer). These variations in grain minerals had nutritional implications primarily favouring the organic grain; however, organic management and, specifically, elimination of soluble fertilizers did not induce dramatic increases in grain mineral concentrations. Ryan 
et al. (2004) emphasized that the effect of organic and traditional farming practices on the Fe content of wheat in Australia was insignificant (Ryan et al. 2004).

Present findings on Fe content of wheat varieties were close to findings of Zhao et al. (2009); Hernandez Rodriguez et al. (2011); Suchowilska et al. (2012); greater than the findings of Al-Gahri and Almussali (2008); Ficco et al. (2009) and lower than findings of Hussain et al. (2010); Nuss and Tanumihardjo (2010); Gao et al. (2012); Kovacevic et al. (2013); Ugulu et al. (2021). In a previous study, genotype xenvironment interaction was also found to be significant in terms of iron content (Ciudad-Mulero et al. (2021).

Manganese (Mn): Average Mn content of entire treatments was 76.9 ppm. Kırik and Doğu-88 cultivars had 77.5 and 81.8 ppm Mn contents, respectively. Manganese concentrations of weedy control, hand weeding, and dense sowing were $81.2,80.4$ and $77.2 \mathrm{ppm}$, respectively and manganese concentrations of control, NP, Bio, Bio SR, Leonardit, OF and CM fertilizer sources were 106.8, 58.8, 92.1, 96.9, 56.8, 70.5 and 75.8 ppm, respectively.

Olgun et al. (2017) reported mean Mn content as $9.01 \mathrm{mg} / \mathrm{kg}$ for 12 bread wheat cultivars In the present study mean Mn content of two wheat cultivars was $76.9 \mathrm{mg} / \mathrm{kg}$ which was much more higher that the finding of Gao et al. (2012), Kovacevic et al. (2013) and Olgun et al. (2017). The higher Mn content of two wheat cultivar might be due genetic make up of cultivars and different environmental factors (Zhao et al. 2009; Jaskulska et al, 2018).

Selenium (Se): Although selenium (Se) is not considered essential element for the healthy growing plants, it is an essential micronutrient for both humans and animals. In humans and livestock, Se is incorporated into a number of functional selenoproteins such as the antioxidant glutathione (GSH) peroxidase enzymes (Kumar et al. 2011). Wheat is also a good source of trace minerals like Se and Mg which is essential nutrients for good health (Shewry et al. 2006; Topping, 2007). There is also increasing evidence that Se plays an important protective role both in the human immune system and in the prevention and suppression of a number of specific disorders such as carcinomas, cardiovascular diseases, cystic fibrosis and low fertility (Fairweather-Tait SJ, 1997; Strauss 1999). Average Se content of entire treatments was 0.549 ppm. Kırik and Doğu-88 cultivars had 0.671 and 0.427 ppm Se contents, respectively. Selenium content of weedy control, hand weeding, and dense sowing were $0.637,0.551$ and $0.458 \mathrm{ppm}$, respectively and Se content of control, NP, Bio, Bio SR, Leonardite, OF and CM fertilizer sources were $0.911,0.230,0.364,0.628,1.136,0.306$ and $0.271 \mathrm{ppm}$ respectively.

Soils are frequently low in available Se, and hence the food sources of many countries are deficient in Se (Rayman 2002; Lyons et al. 2003). Selenium availability in soils depends upon soil pH, redox potential, calcium carbonate level, cation exchange capacity, and organic carbon, iron (Fe) and aluminum (Al) levels (Lyons et al. 2005). Similar to present results, Se content for wheat have been variable (Lyons et al. 2005). 
Zinc (Zn): Average of entire treatments was found to be 11.34 ppm. Kırik and Doğu-88 cultivars had zinc concentrations respectively of 13.25 and 9.43 ppm; zinc concentrations of weedy control, hand weeding, and dense sowing were respectively determined as $10.54,11.39$ and 12.09 ppm; and zinc concentrations of control, NP, Bio, Bio SR, Leonardite, OF and CM fertilizer sources were respectively found to be 17.51 , $6.14,12.33,9.47,9.24,9.48$ and $15.25 \mathrm{ppm}$.

Two factors contribute to the low contents of bioavailable iron and zinc in wheat: the low concentrations of these minerals in white flour, which is most widely consumed, and the presence of phytates in mineralrich bran fractions (Balk et al. 2019). The results of the present study indicated that $\mathrm{Zn}$ contents in wheat samples (overall mean $11.34 \mathrm{ppm}$ ) were below the permissible limit $99.4 \mathrm{mg} / \mathrm{kg}$ as given by the FAO/WHO (2001). Regionally, grain Fe and Zn concentration was found to be lower in high-yielding regions. The concentration of $\mathrm{Zn}$ ranged from 12.95 to $25.83 \mathrm{mg} / \mathrm{kg}$ in the grains of the wheat variety (Lasani-08) (Ugulu et al. (2021) and 16.41 to $24.80 \mathrm{mg} / \mathrm{kg}$ in the grains of 12 bred wheat varieties (Olgun et al. 2017). Differences in grain Zn contents among varieties could be associated with differences in adaptation ability of genotypes. Our results were found to be lower than the results obtained (35.3 $\mathrm{mg} / \mathrm{kg}$ ) from wheat applied wastewater by Hassan et al. (2013) in Pakistan. Tarighi et al. (2012) reported that the $\mathrm{Zn}$ content of wheat varieties enriched with cattle manure varied in the range of 9-30 mg kg-1 and the difference between varieties was significant. Tarighi et al. (2012) In general, cultivation of wheat plant (cv. Backcross) resulted in a lower Zn uptake relative to the Alvand cultivar. However, the plants $\mathrm{Zn}$ concentration of both cultivars depended on the rate and type of the applied manure (organic or inorganic sources). Both cultivars showed that plants grown in soil treated with $\mathrm{ZnSO} 4$ accumulated significantly greater $\mathrm{Zn}$ in their root tissue compared to those grown in soil treated with cow manure. A significant increase in the shoot, spike and root Zn concentration was observed as the loading rate of cow manure increased. Ghambari and Mameesh (1971) reported that wheat Fe content was significantly influenced by date of planting but not by seeding rates or nitrogen fertilization.

Cadmium (Cd): Average Cd content of entire treatments was 0.012 ppm. Kırik and Doğu-88 cultivars had 0.01212 and 0.01235 ppm Cd concentrations, respectively. Cadmium concentrations of weedy control, hand weeding, and dense sowing were as $0.01437,0.01183$ and $0.01051 \mathrm{ppm}$, respectively and Cd concentrations of control, NP, Bio, Bio SR, Leonardite, OF and CM fertilizer sources were $0.02417,0.00335$, $0.01722,0.01267,0.01076,0.00943$ and 0.00809 ppm respectively. Cadmium was extensively used in pigments, batteries, plastics, and metal coatings. The effects of $\mathrm{Cd}$ are known to be carcinogenic (Khan et al. 2019). According to the treatment, the average Cd content of wheat was $0.012 \mathrm{ppm}$. Our findings are in line with Stefanovic's findings in Serbia (Stefanovic et al. 2008). This value was found to be very much lower than the value $(0.925-0.98 \mathrm{mg} / \mathrm{kg}$ ) obtained from the study conducted on wheat in Pakistan (Ugulu et al. (2021). The fact that the soils where the study was conducted were not exposed to chemical contamination may have revealed these results. In this study, the concentration of $\mathrm{Cd}$ was present within the safe limit $(0.2 \mathrm{mg} / \mathrm{kg}$ ) reported by the FAO/WHO (2001). Further, low amounts of heavy metals, especially of $\mathrm{Cd}$ and $\mathrm{Pb}$ are regarded as of considerable importance (Hussain, 2012). None of the genotypes investigated in this study reached the maximum permitted value for $\mathrm{Pb}$ and $\mathrm{Cd}(\mathrm{EC}, 2006)$. 
Today, microelement malnutrition is considered worldwide problem and about a half of the world's population is suffering from microelement malnutrition (Welch and Graham, 2004).

Cobalt (Co): Average Co content of entire treatments was 0.140 ppm. Kırik and Doğu-88 cultivars had 0.160 and $0.121 \mathrm{ppm}$ cobalt concentrations, respectively. Cobalt concentrations of weedy control, hand weeding, and dense sowing were $0.132,0.156$ and $0.133 \mathrm{ppm}$, respectively and Co concentrations of control, NP, Bio, Bio SR, Leonardite, OF and CM fertilizer sources were $0.221,0.049,0.173,0.099,0.258$, 0.092 and $0.095 \mathrm{ppm}$, respectively.

In a study on wheat grain, flour and seed coat, the concentration of Co was found to be in the range of 1.036 to $1.113 \mathrm{mg} / \mathrm{kg}$ (Ugulu et al. (2021). These results, which were carried out in Pakistan s, were found to be higher than our results. According to these findings, all Co concentrations in wheat grains were found below the permissible limit $50 \mathrm{mg} / \mathrm{kg}$ as given by the FAO/WHO (2001). Concentrations were significantly lower in treatments with NPK fertilizer than in unfertilized grain. Adding organic resources such as crop residues, green manure and livestock manure to soil has a number of beneficial effects on micronutrient nutrition including additional supply of some nutrients with the added organic matter, increase in ion exchange capacity and thus of the fractions of easily available nutrients, improved soil structure, increased accessibility of soil for plant roots, stimulation of microbial activities. All these effects promote plant growth, development of the root system and thus also its capacity to acquire micronutrients (Schulin et al. 2009).

Chrome (Cr): The chromium compounds are usually toxic and carcinogenic to humans. It can be found in all forms such as liquid, gas, or solid state in plants, animals, and rocks (Dogan et al. 2014). Average $\mathrm{Cr}$ content of entire treatments was $0.194 \mathrm{ppm}$. Kırik and Doğu-88 cultivars had 0.122 and $0.166 \mathrm{ppm} \mathrm{Cr}$ concentrations, respectively. Chrome concentrations of weedy control, hand weeding, and dense sowing were $0.212,0.212$ ve 0.158 ppm, respectively and $\mathrm{Cr}$ concentrations of control, NP, Bio, Bio SR, Leonardite, OF and CM fertilizer sources were $0.415,0.095,0.243,0.220,0.127,0.129$ and 0.134 ppm, respectively. Concentrations of $\mathrm{Cr}$ in grain were of the same level as reported by Andersson (1992) for Swedish wheat grain varying between 0.01 and $0.03 \mathrm{mg} / \mathrm{kg}$ grain dry weight. Chromium concentrations in manure fertilized grain were significantly higher than in NPK fertilized wheat. In a study conducted with different organic fertilizer sources and Lasani-08 wheat cultivar in Pakistan, the $\mathrm{Cr}$ content varied between 0.493 to $1.154 \mathrm{mg} / \mathrm{kg}$ (Ugulu et al. (2021). Chromium concentrations decreased in NPK-fertilized grain and amounted to $0.01 \mathrm{mg} \mathrm{Cr} / \mathrm{kg}$ after 40 years (Kirchmann et al. (2009). On the other hand, it has been reported by Wyszkowski and Brodowska, (2020) that the $\mathrm{Cr}$ content increased by $15 \%$ with nitrogen fertilization. Cary et al. (1975) found a highly significant relationship between Fe and $\mathrm{Cr}$ concentrations in wheat seeds. The Crvalues obtained from the current study are well below the level that will pose a health risk.

Nickel (Ni): Average Ni content of the entire treatments was $3.71 \mathrm{ppm}$. Kırik and Doğu-88 cultivars had 3.42 and 4.00 ppm Ni concentrations, respectively. ; Nickel concentrations of weedy control, hand weeding, and dense sowing were 3.76, 4.30 and 3.07 ppm, respectively and Ni concentrations of control, 
NP, Bio, Bio SR, Leonardite, OF and CM fertilizer sources were 8.85, 1.71, 3.75, 4.36, 2.50, 2.37 and 2.45 ppm, respectively. Similar to our results, Hamner et al. (2013) has stated that application of inorganic fertilizer (NPK) decreased Ni concentrations in wheat grain compared with the unfertilized treatment. Higher rates of mineral $\mathrm{N}$ fertilization caused a decrease in Ni concentration in wheat grain compared with unfertilized treatments in the long-term field trials (Hamner et al. 2013). Long-term manure application did not lead to increased Ni concentrations in crops either. Their results indicate that application of sewage sludge or cattle manure at permitted rates of 700 and $3000 \mathrm{~kg} / \mathrm{ha}$ per year did not increase Ni concentration in the tested crops (Hamner et al. 2013).

Lead $(\mathrm{Pb})$ : Average $\mathrm{Pb}$ content of entire treatments was 0.269 ppm. Kırik and Doğu-88 cultivars had 0.268 and $0.271 \mathrm{ppm} \mathrm{Pb}$ concentrations, respectively. Lead concentrations of weedy control, hand weeding, and dense sowing were $0.254,0.271$ and $0.283 \mathrm{ppm}$, respectively and $\mathrm{Pb}$ concentrations of control, NP, Bio, Bio SR, Leonardite, OF and CM fertilizer sources were 0.630, 0.052, 0.117, 0.354, 0.571, 0.090 and 0.076 $\mathrm{ppm}$, respectively. Our findings for Pb contents were higher than Stefanovic's findings (Stefanovic et al. 2008). In Pakistan, the determined mean $\mathrm{Pb}$ contents of the wheat grain were between 0.504 and 1.997 $\mathrm{mg} / \mathrm{kg}$. This $\mathrm{Pb}$ values were much higher than the permissible limit $(0.30 \mathrm{mg} / \mathrm{kg})$ suggested by the FAO/WHO (2001) (Ugulu et al. (2021). The values (mean $0.269 \mathrm{ppm}$ ) determined in the current study were also lower than the permissible $\mathrm{Pb}$ limits. But are also higher than the $\mathrm{Pb}$ values $(0.06$ to $0.2 \mathrm{mg} / \mathrm{kg})$ in wheat samples irrigated with wastewater in Sargodha City (Pakistan) (Ahmad et al. (2019). Mineral element uptake of plants may be influenced by soil, genetic factors and environment effects (Stefanovic et al. 2008; Zhang et al. 2014).

\section{Conclusions}

Wheat is included daily diets of almost all cultures. However, number of studies about the effects of agronomic practices on quality traits, especially of mineral composition of wheat species is not sufficient. Therefore, the present study was conducted to determine the effects of agronomic practices on the mineral content of organic wheat production. In terms of all nutrients evaluated, the mineral content of wheat showed significant differences according to crop years, varieties, weed control methods and fertilizer sources. Such variations were mostly attributed to environmental and genetic factors and their interactions. As the average of all factors, the $\mathrm{Cu}, \mathrm{Fe}, \mathrm{Mn}, \mathrm{Se}, \mathrm{Zn}, \mathrm{Cd}, \mathrm{Co}, \mathrm{Cr}, \mathrm{Ni}$ and $\mathrm{Pb}$ contents of the ground wheat grain were; $3.93,42.8,79.6,0.549,11.34,0.012,0.140,0.194,3.71$ and $0.269 \mathrm{mg} / \mathrm{kg}$, respectively. According to the wheat varieties, the Kırik was superior in terms of $\mathrm{Cu}, \mathrm{Fe}, \mathrm{Se}, \mathrm{Zn}, \mathrm{Co}$ and $\mathrm{Cr}$, and the Dogu-88 was superior in terms of $\mathrm{Mn}, \mathrm{Cd}$, and $\mathrm{Ni}$. The effect of weed control methods on mineral content was variable. According to fertilizer sources, the highest mineral content was obtained from the non-fertilizer applied control plots. The lowest mineral contents were obtained from chemical fertilization, cattle manure and organic fertilizer applications. There was no significant increase in the mineral content of wheat with organic fertilization, however, organic agriculture still preserves its place in terms of healthy food. As a result, it has been determined that the values obtained for all mineral elements were not at a level that pose a risk to the environment, human and animal health according to WHO. 


\section{Declarations}

\section{ACKNOWLEDGEMENTS}

The authors thanks to TÜBITAK, Agricultural Research and Extension Center of Ataturk University and Technology Research and Application Center (TAUM) of Erciyes University for their convenience in project, field and laboratory studies.

\section{References}

Ahmad K., Wajid K., Khan Z.I., Ugulu I., Memoona H., Sana M., Nawaz K., Malik I.S., Bashir H., Sher M. 2019. Evaluation of potential toxic metals accumulation in wheat irrigated with wastewater. Bull Environ Contam Toxicol, 102: 822-828.

Al-Gahri M.A., Almussali M.S. 2008. Microelement contents of locally produced and imported wheat grains in Yemen. J. Chem. 5: 838-843.

Andersson A. 1992. Trace elements in agricultural soils-fluxes, balances and background values. Swedish Environmental Protection Agency, Report No. 4077. Stockholm.

Anglani C. 1998. Wheat minerals - A review. Plant Foods for Human Nutrition 52: 177-186.

Balk J., Connorton J.M., Wan Y., Lovegrove A., Moore K.L., Uauy C., Sharp P.A., Shewry P.R. 2019. Improving wheat as a source of iron and zinc for global nutrition. Nutrition Bulletin 44, 53-59. doi:10.1111/nbu.12361

Cary E.E., Allaway W.H., Olson O.E. 1975. Control of chromium concentrations in food plants. 1. Absorption and translocation of chromium by plants. Journal of Agricultural Food and Chemistry, 25 : 300-304.

Chen J., Jiang Y., Shi H., Peng Y., Fan X., Li C. 2020. The molecular mechanisms of copper metabolism and its roles in human diseases. Pflügers Archiv-European Journal of Physiology, 472: 1415-1429.

Ciudad-Mulero M., Matallana-González M.C., Callejo M.J., Carrillo J.M., Morales P., Fernández-Ruiz V. 2021. Durum and Bread Wheat Flours. Preliminary Mineral Characterization and Its Potential Health Claims. Agronomy, 11: 108 (1-13).

Conti M.E., Cubadda F., Carcea M. 2000. Trace metals in soft and durum wheat from Italy. Food Additives and Contaminants, 17(1): 45-53.

Dogan Y., Baslar S., Ugulu I. 2014. A study on detecting heavy metal accumulation through biomonitoring: content of trace elements in plants at Mount Kazdagi in Turkey. Appl. Ecol. Environ. Res. 12(3): 627-636. 
Dogan Y., Ugulu I., Baslar S. 2010. Turkish red pine as a biomonitor: a comparative study of the accumulation of trace elements in needles and barks. Ekoloji, 19(75): 88-96.

EC, Commission Regulation (EC) No. 1881/2006 of 19 December 2006 setting maximum levels for certain contaminants in foodstuffs. Off J. Eur. Union L364/5.

Fairweather-Tait S.J. 1997. Bioavailability of selenium. Eur. J. Clin. Nutr. 51: 20-23.

FAO 2001. Codex Alimentarius Commission. Food additive and contaminants. Joint FAO/ WHO Food Standards Programme, ALINORM 01/ 12A, pp. 1-289

Ficco D.B.M., Riefolo C., Nicastro G., De Simone V., Di Gesu A.M., Beleggia R. 2009. Phytate and mineral elements concentration in a collection of Italian durum wheat cultivars. Field Crops Res. 111: 235-242.

Gao X., Lukow O.M., Grant C.A. 2012. Grain concentrations of protein, Fe and Zn and bread making quality in spring wheat as affected by seeding date and nitrogen fertilizer management. J. Geochem. Explor. 121: 36-44.

Ghanbari G.A., Mameesh M.S. 1971. Iron, zinc, manganese, and copper content of semidwarf wheat varieties grown under different agronomic conditions. Cereal Chem. 48: 411-414.

Grzeszczak K., Kwiatkowski S., Kosik-Bogacka D. 2020. The Role of Fe, Zn, and Cu in Pregnancy. Biomolecules, 10(8): 1176 (2-34).

Hamner K., Eriksson J., Kirchmann H. 2013. Nickel in Swedish soils and cereal grain in relation to soil properties, fertilization and seed quality. Acta Agriculturae Scandinavica, Section B-Soil \& Plant Science, 63: $712-722$.

Hassan N.U., Mahmood Q., Waseem A., Irshad M., Faridullah M., Pervez A. 2013. Assessment of heavy metals in wheat plants irrigated with contaminated wastewater. Polish J. Environ. Stud. 22(1): 115-123.

Hernandez Rodriguez L., Afonso Morales D., Rodriguez Rodriguez E., Diaz Romero C. 2011. Minerals and trace elements in a collection of wheat landraces from the Canary Islands. J. Food Compos. Anal. 24: 1081-1090.

Hussain A., Larsson H., Kuktaite R., Johansson E. 2010. Mineral composition of organically grown wheat genotypes: contribution to daily minerals intake. Int. J. Environ. Res. Public Health, 7: 3442-3456.

Hussain A., Larsson H., Kuktaite R., Johansson E. 2012. Healthy food from organic wheat: choice of genotypes for production and breeding. Journal of the Science of Food and Agriculture, 92(14): 28262832.

Jaskulska I., Jaskulski D., Gałęzewski L., Knapowski T., Kozera W., Wacławowicz R. 2018. Mineral composition and baking value of the winter wheat grain under varied environmental and agronomic 
conditions. Journal of Chemistry, Vol. 2018, Article ID 5013825, 7 pages, 2018. https://doi.org/10.1155/2018/5013825

Khan Z.I., Nisar A., Ugulu I., Ahmad K., Wajid K., Bashir H., Dogan Y. 2019. Determination of cadmium concentrations of vegetables grown in soil irrigated with wastewater: evaluation of health risk to the public. Egypt J. Bot. 59(3): 753-762.

Kirchmann H., Mattsson L., Eriksson J. 2009. Trace element concentration in wheat grain: results from the Swedish long-term soil fertility experiments and national monitoring program. Environmental Geochemistry and Health, 31: 561-571.

Klevay L.M. 2000. Cardiovascular disease from copper deficiency-a history. J. Nutr. 130(2): 489-492.

Kovacevic V., Kadar I., Rastija M., Iljkic D. 2013. Response of maize and winter wheat to liming with hydratized lime. Novenytermeles, 62: 47-50.

Kumar P., Yadava R.K., Gollen B., Kumar S., Verma R.K., Yadav S. 2011. Nutritional Contents and Medicinal Properties of Wheat. A Review. Life Sciences and Medicine Research, Volume 2011: LSMR-221.

Lakhdar A., Achiba W.B., Montemurro F., Jedidi N., Abdelly C. 2009. Effect of municipal solid waste compost and farmyard manure application on heavy-metal uptake in wheat. Commun. Soil Sci. Plant. Anal. 40: 3524-3538.

Lyons G.H., Stangoulis J.C.R., Graham R.D. 2003. Nutritional Research Review, 16: 45- 60.

Lyons G.H., Ortiz-Monasterio I., Stangoulis J., Graham R.D. 2005. Selenium concentration in wheat grain: Is there sufficient genotypic variation to use in breeding? Plant and Soil 269: 369-380.

Munir M., Khan Z.I., Ahmad K., Wajid K., Bashir H., Malik I.S., Nadeem M., Ashfaq A., Ugulu I. 2019. Transfer of heavy metals from different sources of fertilizers in wheat variety (Galaxy-13). Asian J. Biol. Sci. 12(4): 832-841.

Nuss E.T., Tanumihardjo S.A. 2010. Maize: a paramount staple crop in the context of global nutrition. Compr. Rev. Food Sci. Food Saf. 9: 417-436.

Olgun M., Ardıç M., Turan M., Sezer O., Budak Başçiftçi Z., Ayter G., Koyuncu O. 2017. Changes in the mineral contents of bread wheat genotypes during the development periods of wheat. Selcuk Journal of Agriculture and Food Sciences, 30(2): 79-87.

Ozturk A., Bulut S., Yildiz N., Karaoglu M.M. 2012. Effects of organic manures and non-chemical weed control on wheat: I-Plant growth and grain yield. J. of Agric. Sci. 18(1): 9-20.

Rayman M.P. 2002. The argument for increasing selenium intake. Proceedings of the Nutrition Society, 61(2): 203-215. 
Ryan M., Derrick J., Dann P. 2004. Grain mineral concentrations and yield of wheat grown under organic and conventional management. J. Sci. Food Agri. 84: 207-216.

Schulin R., Khoshgoftarmanesh A., Afyuni M., Nowack B., Frossard E. 2009. Effect of soil management on zinc uptake and its bioavailability in plants, in: Banuelos G.S., Lin Z. (Eds.), Development and uses of biofortified agricultural products, CRC Press, Boca Raton, Fillandia.

Shewry P.R., Powers S., Field J.M., Fido R.J., Jones H.D., Arnold G.M., West J., Lazzeri P.A., Barcelo P., Barro F., Tatham A.S., Bekes F., Butow B., Darlington H. 2006. Comparative field performance over three years and two sites of transgenic wheat lines expressing HMW subunit transgenes. Theoretical and Applied Genetics, 113: 128-136.

Shewry P.R., Hey S.J. 2015. The contribution of wheat to human diet and health. Food and Energy Security, 4(3): 178-202.

Siddique S., Ahmad K., Khan Z.I., Wajid K., Bashir H., Munir M., Nadeem M., Noorka I.R., Malik I.S., Ashfaq A., Ugulu I., Akhtar M., Akhtar P., Mehmood N., Muqadas H., Shehzadi M. 2019. Sodium status of soil, forages, and small ruminants of Punjab, Pakistan. Pure Appl. Biol. 8(3): 1950-1961.

Skrbic B., Onjia A. 2007. Multivariate analyses of microelement contents in wheat cultivated in Serbia 2002. Food Control, 18 (4): 338-345.

Stefanovic V.Z., Filipovic N.K., Jovanovic B.M. 2008. Undesirable Metals Content in Wheat of Different Wheat Varreties. APTEFF, 39: 69-76.

Strauss E. 1999. Developmental biology-selenium's role in infertility explained. Science 285: 1339.

Suchowilska E., Wiwart M., Kandler W., Krska R. 2012. A comparison of macro- and microelement concentrations in the whole grain of four Triticum species. Plant Soil Environ. 58: 141-147.

Tarighi H., Majidian M., Baghaie A.H., Gomarian M. 2012. Zinc availability of two wheat cultivars in soil amended with organic and inorganic Zn sources. African Journal of Biotechnology, 11(2): 436-443.

Topping D. 2007. Cereal complex carbohydrates and their contribution to human health. Journal of Cereal Science, 46: 220-229.

Ugulu I., Ahmad K., Khan Z.I., Munir M., Wajid K., Bashir H. 2021. Effects of organic and chemical fertilizers on the growth, heavy metal/metalloid accumulation, and human health risk of wheat (Triticum aestivum L.). Environ. Sci. Pollut. Res. Int. 28(10): 12533-12545.

Wajid K., Ahmad K., Khan Z.I., Nadeem M., Bashir H., Chen F., Ugulu I. 2020. Effect of organic manure and mineral fertilizers on bioaccumulation and translocation of trace metals in maize. Bull. Environ. Contam. Toxicol, 104: 649-657. 
Welch R.M., Graham R.D. 2004. Breeding for micronutrients in staple food crops from a human nutrition perspective. J. Exp. Bot. 55: 353-364.

WHO World Health Organization, 2013. World Health Report: Research for Universal Health Coverage. World Health Organization: Geneva, Switzerland.

WHO World Health Organization, 2015. The Global Prevalence of Anaemia in 2011. World Health Organization: Geneva, Switzerland.

Wyszkowski M., Brodowska M.S. 2020. Content of Trace Elements in Soil Fertilized with Potassium and Nitrogen. Agriculture, 10(9): 398.

Zhang M.Y., Yang Y.H., Feng C.N., Guo W.S., Li C.Y., Zhu X.K. 2014. Responses of concentration of mineral to zinc biofortification in different wheat genotyes. J. Triticeae Crops 34: 489-94.

Zhao F.J., Su Y.K., Dunham S.J., Rakszegi M., Bedob Z., McGrath S.P., Shewryc P.R. 2009. Variation in mineral micronutrient concentrations in grain of wheat lines of diverse origin. Journal of Cereal Science, 49(2): 290-295.

\section{Tables}

Table 1. Copper (Cu), Iron (Fe), Manganese (Mn), Selenium (Se) and Zinc (Zn) concentrations of organic wheat under some treatments' * 


\begin{tabular}{|c|c|c|c|c|c|}
\hline & $\mathrm{Cu}(\mathrm{ppm})$ & Fe (ppm) & Mn (ppm) & Se (ppm) & Zn (ppm) \\
\hline \multicolumn{6}{|l|}{ Years } \\
\hline 2006-07 & $3.10 \mathrm{c}$ & $26.6 \mathrm{c}$ & $64.4 \mathrm{c}$ & $0.321 \mathrm{c}$ & $8.13 \mathrm{c}$ \\
\hline 2007-08 & $4.87 \mathrm{a}$ & $61.5 \mathrm{a}$ & $95.9 \mathrm{a}$ & $0.821 \mathrm{a}$ & $15.34 \mathrm{a}$ \\
\hline 2008-09 & $3.83 \mathrm{~b}$ & $40.3 \mathrm{~b}$ & $78.6 \mathrm{~b}$ & $0.505 \mathrm{~b}$ & $10.55 \mathrm{~b}$ \\
\hline Average & 3.93 & 42.8 & 79.6 & 0.549 & 11.34 \\
\hline \multicolumn{6}{|l|}{ Cultivars } \\
\hline Kırik & $4.08 \mathrm{a}$ & $43.6 \mathrm{a}$ & $77.5 \mathrm{~b}$ & $0.671 \mathrm{a}$ & $13.25 \mathrm{a}$ \\
\hline Doğu-88 & $3.79 \mathrm{~b}$ & $42.0 \mathrm{~b}$ & $81.8 \mathrm{a}$ & $0.427 \mathrm{~b}$ & $9.43 \mathrm{~b}$ \\
\hline \multicolumn{6}{|l|}{ Weed control } \\
\hline Weedy control & $3.75 \mathrm{~b}$ & $46.1 \mathrm{a}$ & $81.2 \mathrm{a}$ & $0.637 \mathrm{a}$ & $10.54 \mathrm{c}$ \\
\hline Hand weeding & $3.67 \mathrm{c}$ & $44.5 \mathrm{~b}$ & $80.4 \mathrm{~b}$ & $0.551 \mathrm{~b}$ & $11.39 \mathrm{~b}$ \\
\hline Dense sowing & $4.38 \mathrm{a}$ & $37.8 \mathrm{c}$ & $77.2 \mathrm{c}$ & $0.458 \mathrm{c}$ & $12.09 \mathrm{a}$ \\
\hline \multicolumn{6}{|l|}{ Fertilizers } \\
\hline Control & $6.74 \mathrm{a}$ & $60.2 \mathrm{a}$ & $106.8 \mathrm{a}$ & $0.911 \mathrm{~b}$ & $17.51 \mathrm{a}$ \\
\hline NP & $1.75 \mathrm{f}$ & $27.7 \mathrm{~g}$ & $58.8 \mathrm{f}$ & $0.230 \mathrm{~g}$ & $6.14 \mathrm{e}$ \\
\hline Bio & $5.47 \mathrm{~b}$ & $45.1 \mathrm{c}$ & $92.1 \mathrm{c}$ & $0.364 \mathrm{~d}$ & $12.33 \mathrm{c}$ \\
\hline Bio SR & $4.79 \mathrm{c}$ & $50.8 \mathrm{~b}$ & $96.9 \mathrm{~b}$ & $0.628 \mathrm{c}$ & $9.47 \mathrm{~d}$ \\
\hline Leonardit & $2.80 \mathrm{e}$ & $41.9 \mathrm{~d}$ & $56.8 \mathrm{~g}$ & $1.136 \mathrm{a}$ & $9.24 \mathrm{~d}$ \\
\hline $\mathrm{OF}$ & $3.03 \mathrm{~d}$ & $34.2 \mathrm{f}$ & $70.5 \mathrm{e}$ & $0.306 \mathrm{e}$ & $9.48 \mathrm{~d}$ \\
\hline $\mathrm{CM}$ & $2.99 \mathrm{~d}$ & $40.0 \mathrm{e}$ & $75.8 \mathrm{~d}$ & $0.271 \mathrm{f}$ & $15.25 \mathrm{~b}$ \\
\hline$\overline{\operatorname{Year}(\mathrm{Y})}$ & $2294.37 * *$ & $4522.46^{* *}$ & $4055.00^{* *}$ & $1584.93^{* *}$ & $3398.26 * *$ \\
\hline Cultivar (C) & $187.66^{* *}$ & $26.58 * *$ & $227.53^{* *}$ & $1115.03^{* *}$ & $2766.30 * *$ \\
\hline Weed control (W) & $430.90 * *$ & $284.39 * *$ & $72.84^{* *}$ & $200.04^{* *}$ & $151.33 * *$ \\
\hline Fertilizer $(\mathrm{F})$ & $3894.10^{* *}$ & $713.55^{* *}$ & $2616.09 * *$ & $1338.52^{* *}$ & $1670.00 * *$ \\
\hline $\mathrm{Y} \times \mathrm{C}$ & $35.41^{* *}$ & $108.82 * *$ & $46.95^{* *}$ & $18.23^{* *}$ & $394.83 * *$ \\
\hline $\mathrm{Y} \times \mathrm{W}$ & $80.48^{* *}$ & $1179.69 * *$ & $14.91 * *$ & $3.22 * *$ & $21.50 * *$ \\
\hline $\mathrm{Y} \times \mathrm{F}$ & $165.24^{* *}$ & $72.10 * *$ & $35.72 * *$ & $161.46^{* *}$ & $30.86^{* *}$ \\
\hline $\mathrm{C} \times \mathrm{W}$ & $114.56^{* *}$ & $32.95 * *$ & $122.70 * *$ & $254.03 * *$ & $14.07^{* *}$ \\
\hline $\mathrm{C} \times \mathrm{F}$ & $98.98 * *$ & $101.29 * *$ & $164.86 * *$ & $302.34 * *$ & $87.83^{* *}$ \\
\hline $\mathrm{W} \times \mathrm{F}$ & $128.36 * *$ & $95.77 * *$ & $115.25 * *$ & $51.67 * *$ & $131.45^{* *}$ \\
\hline $\mathrm{Y} \times \mathrm{C} \times \mathrm{W}$ & $53.73 * *$ & $87.59 * *$ & $77.67 * *$ & $32.28 * *$ & $61.81^{* *}$ \\
\hline $\mathrm{Y} \times \mathrm{C} \times \mathrm{F}$ & $39.14^{* *}$ & $45.27 * *$ & $13.28 * *$ & $12.23^{* *}$ & $52.78^{* *}$ \\
\hline $\mathrm{Y} \times \mathrm{W} \times \mathrm{F}$ & $40.58 * *$ & $51.89 * *$ & $32.56^{* *}$ & $30.11 * *$ & $30.74 * *$ \\
\hline $\mathrm{C} \times \mathrm{W} \times \mathrm{F}$ & $128.87 * *$ & $89.61 * *$ & $54.81 * *$ & $114.67 * *$ & $77.01 * *$ \\
\hline $\mathrm{Y} \times \mathrm{C} \times \mathrm{W} \times \mathrm{F}$ & $62.00 * *$ & $60.00 * *$ & $37.29 * *$ & $37.84^{* *}$ & $11.14^{* *}$ \\
\hline Variation coefficient (\%) & 5.28 & 6.85 & 3.48 & 12.96 & 6.23 \\
\hline
\end{tabular}

1 The difference between means with the same letter is not significant $(\mathrm{P}<0.01)$. 
* The difference between means with different letters is significant at $\mathrm{p}<0.01$ level.

Table 2. Cadmium (Cd), Cobalt (Co), Chrome (Cr), Nickel (Ni) and Lead $(\mathrm{Pb})$ concentrations of organic wheat under some treatments' $*$ 


\begin{tabular}{|c|c|c|c|c|c|}
\hline & $\mathrm{Cd}(\mathrm{ppm})$ & Co (ppm) & Cr (ppm) & $\mathrm{Ni}(\mathrm{ppm})$ & $\mathrm{Pb}(\mathrm{ppm})$ \\
\hline \multicolumn{6}{|l|}{ Years } \\
\hline 2006-07 & $0.002 \mathrm{c}$ & $0.078 \mathrm{c}$ & $0.093 \mathrm{c}$ & $2.28 \mathrm{c}$ & $0.081 \mathrm{c}$ \\
\hline 2007-08 & $0.026 \mathrm{a}$ & $0.220 \mathrm{a}$ & $0.326 \mathrm{a}$ & $5.23 \mathrm{a}$ & $0.544 \mathrm{a}$ \\
\hline 2008-09 & $0.008 \mathrm{~b}$ & $0.123 \mathrm{~b}$ & $0.163 \mathrm{~b}$ & $3.62 \mathrm{~b}$ & $0.183 \mathrm{~b}$ \\
\hline Average & 0.012 & 0.140 & 0.194 & 3.71 & 0.269 \\
\hline \multicolumn{6}{|l|}{ Cultivars } \\
\hline Kirik & $0.01212 \mathrm{~b}$ & $0.160 \mathrm{a}$ & $0.222 \mathrm{a}$ & $3.42 \mathrm{~b}$ & 0.268 \\
\hline Doğu-88 & $0.01235 \mathrm{a}$ & $0.121 \mathrm{~b}$ & $0.166 \mathrm{~b}$ & $4.00 \mathrm{a}$ & 0.271 \\
\hline \multicolumn{6}{|l|}{ Weed control } \\
\hline Weedy control & $0.01437 \mathrm{a}$ & $0.132 \mathrm{~b}$ & $0.212 \mathrm{a}$ & $3.76 \mathrm{~b}$ & $0.254 \mathrm{C}$ \\
\hline Hand weeding & $0.01183 \mathrm{~b}$ & $0.156 \mathrm{a}$ & $0.212 \mathrm{a}$ & $4.30 \mathrm{a}$ & $0.271 \mathrm{~b}$ \\
\hline Dense sowing & $0.01051 \mathrm{c}$ & $0.133 \mathrm{~b}$ & $0.158 \mathrm{~b}$ & $3.07 \mathrm{c}$ & $0.283 \mathrm{a}$ \\
\hline \multicolumn{6}{|l|}{ Fertilizers } \\
\hline Control & $0.02417 \mathrm{a}$ & $0.221 \mathrm{~b}$ & $0.415 \mathrm{a}$ & $8.85 \mathrm{a}$ & $0.630 \mathrm{a}$ \\
\hline NP & $0.00335 \mathrm{~g}$ & $0.049 \mathrm{f}$ & $0.095 \mathrm{e}$ & $1.71 \mathrm{e}$ & $0.052 \mathrm{~g}$ \\
\hline Bio & $0.01722 \mathrm{~b}$ & 0.173 c & $0.243 \mathrm{~b}$ & $3.75 \mathrm{c}$ & $0.117 \mathrm{~d}$ \\
\hline Bio SR & $0.01267 \mathrm{c}$ & $0.099 \mathrm{~d}$ & $0.220 \mathrm{c}$ & $4.36 \mathrm{~b}$ & $0.354 \mathrm{c}$ \\
\hline Leonardit & $0.01076 \mathrm{~d}$ & $0.258 \mathrm{a}$ & $0.127 \mathrm{~d}$ & $2.50 \mathrm{~d}$ & $0.571 \mathrm{~b}$ \\
\hline $\mathrm{OF}$ & $0.00943 \mathrm{e}$ & $0.092 \mathrm{e}$ & $0.129 \mathrm{~d}$ & $2.37 \mathrm{~d}$ & $0.090 \mathrm{e}$ \\
\hline $\mathrm{CM}$ & $0.00809 \mathrm{f}$ & $0.095 \mathrm{de}$ & $0.134 \mathrm{~d}$ & $2.45 \mathrm{~d}$ & $0.076 \mathrm{f}$ \\
\hline$\overline{\operatorname{Year}(\mathrm{Y})}$ & $26419.3 * *$ & $2315.29 * *$ & $2865.82^{* *}$ & $1857.11^{* *}$ & $6700.16^{* *}$ \\
\hline Cultivar (C) & $6.38 *$ & $484.48^{* *}$ & $481.49 * *$ & $214.80^{* *}$ & 0.50 \\
\hline Weed control (W) & $631.30 * *$ & $82.39 * *$ & $194.46^{* *}$ & $320.82^{* *}$ & $24.21^{* *}$ \\
\hline Fertilizer $(\mathrm{F})$ & $3209.16^{* *}$ & $1245.16^{* *}$ & $1068.22^{* *}$ & $2167.38^{* *}$ & $3438.89 * *$ \\
\hline $\mathrm{Y} \times \mathrm{C}$ & $33.12^{* *}$ & $70.53 * *$ & $295.36 * *$ & $10.04^{* *}$ & $150.29 * *$ \\
\hline $\mathrm{Y} \times \mathrm{W}$ & $3470.50 * *$ & $11.85^{* *}$ & $118.98 * *$ & $14.95^{* *}$ & $7200.00 * *$ \\
\hline $\mathrm{Y} \times \mathrm{F}$ & $1000.83^{* *}$ & $119.43^{* *}$ & $142.41 * *$ & $216.57 * *$ & $622.12 * *$ \\
\hline $\mathrm{C} \times \mathrm{W}$ & $426.10 * *$ & $80.29 * *$ & $90.79 * *$ & $12.10^{* *}$ & $158.80 * *$ \\
\hline $\mathrm{C} \times \mathrm{F}$ & $142.50 * *$ & $114.53^{* *}$ & $107.56 * *$ & $80.41^{* *}$ & $43.96 * *$ \\
\hline $\mathrm{W} \times \mathrm{F}$ & $597.06 * *$ & $117.98^{* *}$ & $239.76^{* *}$ & $482.38^{* *}$ & $137.73^{* *}$ \\
\hline $\mathrm{Y} \times \mathrm{C} \times \mathrm{W}$ & $208.97 * *$ & $38.58 * *$ & $175.19 * *$ & $42.97 * *$ & $67.15^{* *}$ \\
\hline $\mathrm{Y} \times \mathrm{C} \times \mathrm{F}$ & $200.33 * *$ & $54.72^{* *}$ & $108.89 * *$ & $52.36^{* *}$ & $217.14^{* *}$ \\
\hline $\mathrm{Y} \times \mathrm{W} \times \mathrm{F}$ & $280.18^{* *}$ & $51.03 * *$ & $125.83 * *$ & $101.93 * *$ & $107.78^{* *}$ \\
\hline $\mathrm{C} \times \mathrm{W} \times \mathrm{F}$ & $346.94 * *$ & $68.03^{* *}$ & $227.20 * *$ & $66.26^{* *}$ & $348.20 * *$ \\
\hline $\mathrm{Y} \times \mathrm{C} \times \mathrm{W} \times \mathrm{F}$ & $204.99 * *$ & $27.99 * *$ & $159.78^{* *}$ & $8.59 * *$ & $134.53^{* *}$ \\
\hline Variation coefficient (\%) & 7.15 & 12.02 & 12.85 & 10.36 & 12.34 \\
\hline
\end{tabular}

1 The difference between means with the same letter is not significant $(\mathrm{P}<0.01)$. 
* The difference between means with different letters is significant at $\mathrm{p}<0.01$ level. 